\title{
Grading on a Curve in Prerequisite Courses and Student Performance in Online Introductory Corporate Finance Classes
}

\author{
Chien-Chih Peng \\ Morehead State University
}

This paper examines whether the practice of grading on a curve in prerequisite courses can affect student performance in online introductory corporate finance classes. The ordinary least squares regression model is employed to analyze a sample of 206 students during the period from 2008 to 2012. The results of this study show that the student's age, major, educational experience, number of hours a student works, and performance in prerequisite courses are significant determinants of student performance. However, the results show no significant difference in student performance in the online introductory corporate finance class between students whose grades were curved and those who did not receive curved grades in prerequisite courses.

\section{INTRODUCTION}

The purpose of this study is to determine whether the practice of grading on a curve in prerequisite courses affects student performance in online introductory corporate finance classes. The idea for this study originates from conversations with online instructors at various education meetings and teaching workshops. These online instructors have been constantly asked questions regarding whether or not curving grades is considered in the course. Students ask the question primarily because introductory corporate finance, one of the required business core courses in any typical business program, is quantitative in nature and it is as difficult to get a high grade in this class as it is to get a good mark in the prerequisite courses such as college algebra, financial accounting, managerial accounting, microeconomics, and macroeconomics. Taking the class online increases the level of difficulty.

Instructors use various grading strategies to determine whether students have achieved course goals for learning, to identify content areas where students are performing well or poorly, and to improve learning activities and assessment practices in the course. While Kulick and Wright (2008) stated that "grading on a curve, in one form or another, is a common practice in higher education" (p. 1), the practice is criticized for lack of flexibility in not allowing more students to earn a top grade and for its inability to distinguish student performance among high quality students. Nevertheless, grading on a curve also receives a lot of support. Instructors who grade on a curve believe that students will be motivated to study if they know that only a limited number of students can receive an 'A' grade. Instructors adopt grading on a curve in their own courses in order to prepare students for curve-grading based standardized tests for professional or graduate schools. Instructors who grade on a curve believe it is an effective way to guard against grade inflation.

Grading on a curve assumes that in classes with large student population, students' scores will most likely follow a normal distribution. Wedell, Parducci, and Roman (1989) argued that "exam scores tend to 
be normally distributed for well-constructed, norm-referenced, multiple choice tests" (p. 239). Grading on a curve does not rule out the possibility that very high scores can be adjusted downward to conform to a normal distribution. However, personal experience indicates that students usually perceive grading on a curve as a practice of assigning extra credit assignments or adding points to all grades to increase the highest test scores to the 100 point level. This practice of mean-shift grading is not grading on a curve but grade inflation, as defined in $\mathrm{Hu}$ (2005). Grade inflation caused by differences in grading standards does exist among business disciplines. Barth, Liu, and Wells (2009) found the average class grades are systematically higher in the Management, Marketing and Logistics disciplines than in the Accounting, Economics and Finance disciplines. Regardless of whether it is categorized as grading on a curve or grade inflation, students' grades are distorted, and information concerned with student proficiency is lost.

Can instructors be confident that students are well-prepared for the online introductory corporate finance class when grading on a curve is utilized in the prerequisite courses? Though research studies show that students who perform well in accounting, economics and mathematics are expected to perform well in introductory corporate finance, this finding may be questionable when students' grades in the prerequisite courses are distorted by the practice of grading on a curve. If students are not well-prepared, it is inevitable that instructors for online introductory corporate finance classes will spend time reviewing basic financial accounting concepts, economic analysis, and algebra. The various instructors who teach prerequisite courses may have different professional ranks, levels of expectation, and grading policies (Hanson, Quinn, \& Wells, 2002; Kezim, Pariseau, \& Quinn, 2005; Sonner, 2000). Moreover, as stated in Stroebe (2016), the practice by university administrators of basing personnel decisions on student evaluations of teaching encourages grading leniency. It creates strong incentives for instructors to teach in ways that entertain the class and require students to do little work to achieve a high grade, thereby resulting in good student evaluations. In effect, students' proficiency in prerequisite courses may not meet with the introductory corporate finance instructors' expectations. Moreover, since these prerequisite courses are challenging courses to most students, it is likely that some instructors practice grading on a curve or inflate students' grades. For example, Kidwell and Kidwell (2008) found that economics, finance, and accounting faculty are more likely to consider grading on a curve regardless of class performance level than faculty in other disciplines. Cluskey and Griffin (1997) found that grade inflation exists in some accounting courses. Becker (1997) also stated "Economics is among the lower-grading departments; thus, economists have room to inflate grades to buy students" (p. 1357). A recent survey conducted by Walstad and Miller (2016) shows that "instructors are willing to adjust grades by giving bonus points, offering extra credit, and increasing a student's grade if it is close to a grade cutoff' ( $p$. 349). Distorted students' grades in these courses may send an unintended and erroneous message about student academic preparedness to online introductory corporate finance instructors.

The goal of this study is to extend existing research studies by taking a closer look at the relationship between student performance in prerequisite courses and student performance in online introductory corporate finance, and examine whether grading on a curve in prerequisite courses can lead to a difference in student performance in online introductory corporate finance. The following sections provide literature review, describe the data and research method, report the results, and provide concluding remarks.

\section{LITERATURE REVIEW}

Educators have identified shortcomings associated with grading on a curve. For example, grading on a curve does not provide feedback as to actual content mastered by the student. The curve used for grading is arbitrary and the curved grades are based on a single class. Grading on a curve discourages student collaboration and promotes competition.

In light of these shortcomings with grading on a curve, researchers have suggested other grading practices. Aviles (2001) advocated the use of criterion-referenced measurements in social work education. The purpose of grading with criterion-reference measurement is to compare student achievement to an instructor-chosen standard (or grading scale according to the university policy). He preferred criterion- 
referenced grading for several reasons. Assigning an 'A' grade to students who only score $60 \%$ on a test of essential materials may not meet the program standard. In addition, grading on a curve may disguise an instructor's teaching deficiencies since students' grades are normalized regardless of what happens in the classroom. Finally, grading on a curve may not prepare students for graduate schools where they must perform against standards and not against other students.

Rapaport (2011) proposed a triage theory of grading to evaluate essay-type assessments. The essence of a triage theory of grading is that questions/assignments to be graded should get full credit (grade ' $A$ ') if and only if they are clearly or substantially correct, minimal credit (grade ' $F$ ') if and only if they are clearly or substantially incorrect, and partial credit (grade ' $C$ ') if and only if they are neither of the above; no other grades should be given. He argued that the triage theory of grading can provide more objective evaluation on student performance and is only concerned with three letter grades, which seems more efficient and effective than varieties of letter grades and percentages generated under normal distribution.

Grading on a curve does not have to follow a normal distribution. Al-Saleh, Ali and Dahshal (2010) illustrated a method to construct a grade-reference curve and a statistical analysis procedure to test for any abnormality in the current semester's grades of a course relative to the constructed curve. For a given course, the grade-reference curve can be obtained based on all grades given to students in the course in the last several years, and be considered as the distribution of the grades of this course for the population of students. The distribution is not confined to the normal distribution. To provide an example, they devised a mathematical procedure to form a chi-squared distribution, and used chi-squared statistics to test for any irregularity of student performance. They suggested that the grade-reference curve of a course is important to students, instructors and administrators. Students can use the grade-reference curve as a guide to set real expectations of their grades in the course and to estimate the effort they should allocate for the course. Instructors use the grade-reference curve to check whether students' grades distribution is similar to (or deviate from) the course grade-reference curve in order to identify areas in teaching that require improvement. Administrators use the grade-reference curve to review the course grades and identify abnormalities or grade inflation.

Kulick and Wright (2008) provided evidence that normally distributed test scores cannot fully distinguish student performance. They used the Monte Carlo simulation to test whether there is a significant correlation between test scores and student knowledge. They predicted that heterogeneous students in low-level college courses should exhibit moderately to strongly positive correlations between student preparation and student performance on course assessments. They also predicted that homogeneous students in high level university courses should exhibit no correlation between preparation and performance. Their simulation results suggested that the practice of grading on a curve cannot distinguish performance among high achieving, academically homogeneous students.

Motivated by the results in Kulick and Wright (2008), Bailey and Steed (2012) empirically investigated the relationship between student preparation and student performance by calculating the correlation coefficients for six major assessments from a common, first-year core course over five semesters. They confirmed Kulick and Wright's prediction that grading on a curve can distinguish performance among academically heterogeneous first-year students. However, in contrast to Kulick and Wright's prediction, their results suggested that grading on a curve can also distinguish performance among a small group of relatively academically homogeneous students in honor classes.

Research studies in online business education have been prolific. Arbaugh, Godfrey, Johnson, Pollack, Niendorf, and Wresch (2009) provided an excellent review and discussion of the literature that examines various issues in online learning in business disciplines. They identified that existing research studies in financial education "can be organized into three categories: technology-mediated education as a classroom supplement, experiences in teaching fully online courses, and web-based financial tools and simulations" (p. 78). As to the impact on student performance, research studies in financial education have shown that students who take introductory corporate finance courses in distance learning formats significantly underperform students in the traditional sections of this course. For example, Shum and Chan (2000) found that remote-site interactive television students have statistically significant poorer performance relative to regular students, and Van Ness, Van Ness, and Adkins (2000) found that students 
who take introductory corporate finance online receive lower grades than those who take the class in a traditional classroom setting. Students who receive poor grades in online introductory corporate finance classes tend to give their instructors poor teaching evaluations. Farinella (2007) stated that a professor who teaches an online section of introductory finance can expect to earn significantly lower student evaluations relative to a traditional section. Chang, Lawrence, and Prakash (2012) also found that the instructors' evaluations are inversely related to the percentage of students expecting poor grades. If grading on a curve in prerequisite courses is one of the determinants affecting student performance in online introductory corporate finance, instructors should consider modifying their teaching strategies in order to obtain better student evaluations.

\section{DATA AND PRELIMINARY ANALYSIS}

This study was conducted at a four-year state university in the Appalachian region of the United States. The School of Business Administration, accredited by the AACSB International (Association to Advance Collegiate Schools of Business), has two departments: Department of Accounting and Finance and Department of Management and Marketing. The Introductory Corporate Finance class is a required core course for all undergraduate business majors. Before taking Introductory Corporate Finance, students are required to complete the prerequisite courses in College Algebra, Principles of Financial Accounting, Principles of Managerial Accounting, Principles of Microeconomics, and Principles of Macroeconomics.

Two hundred six students who completed a survey in the first week of the semester and received a course grade in one of ten sections of Introductory Corporate Finance online classes from 2008 to 2012 were the participants in this empirical study. The students in the sample were taught by only one instructor; therefore, this study avoids the confounding effects of different instructors and different teaching methods. The introductory corporate finance class covers topics such as financial statements and analysis, time value of money, bond and stock valuations, capital budgeting, cost of capital, working capital management, and international financial management.

Table 1 shows the description of the variables used in this study. The variables are primarily associated with student effort, student characteristics, and prerequisite course characteristics. These variables are well documented by Terry (2002) who provided a summary of the results of previous research examining the impact of various factors on performance in accounting, economics and finance courses. As in the studies summarized in Terry (2002), student effort is measured by the student's course grade, which is based on homework assignments (25\%), quizzes (20\%), and exams (55\%). Student characteristics such as gender, in-state/out-of-state status, and major are collected through the faculty advising system at the university. Additional student characteristics such as age, transfer status, number of working hours and prerequisite course characteristics such as student's grades in prerequisite courses and status of grading on a curve practice are collected through survey conducted in the first week of the semesters. These variables have been examined in studies such as Didia and Hasnat (1998), Borde, Byrd, and Modani (1998), Terry (2002), and Raehsler, Hung, Yang, and Stuhldreher (2012). 
TABLE 1

VARIABLE DESCRIPTION

\begin{tabular}{ll}
\hline \hline Variable & Description \\
\hline F360G & Student's course grade recorded as a percentage in Introductory Corporate Finance \\
GENDER & Binary variable: 1 if the student's gender is male; 0 otherwise \\
AGE & Student's age in years when enrolled in introductory corporate finance classes \\
FROM & Binary variable: 1 if the student is an in-state student; 0 otherwise \\
AF & Binary variable: 1 if the student is an accounting or finance major; 0 otherwise \\
TRANSFER & Binary variable: 1 if the student transferred to the university in the study; 0 otherwise \\
WORKHR & Number of hours spent working per week on average \\
M152G & Student's final grade in College Algebra; $\mathrm{A}=4, \mathrm{~B}=3, \mathrm{C}=2, \mathrm{D}=1, \mathrm{E}=0$ \\
$\mathrm{M} 152 \mathrm{C}$ & Binary variable: 1 if the college algebra instructor curved the students' grades; 0 otherwise \\
A281G & Student's final grade in Principles of Financial Accounting; $\mathrm{A}=4, \mathrm{~B}=3, \mathrm{C}=2, \mathrm{D}=1, \mathrm{E}=0$ \\
$\mathrm{~A} 281 \mathrm{C}$ & Binary variable: 1 if the financial accounting instructor curved the students' grades; 0 otherwise \\
A282G & Student's final grade in Principles of Managerial Accounting; $\mathrm{A}=4, \mathrm{~B}=3, \mathrm{C}=2, \mathrm{D}=1, \mathrm{E}=0$ \\
$\mathrm{~A} 282 \mathrm{C}$ & Binary variable: 1 if the managerial accounting instructor curved the students' grades; 0 \\
& otherwise \\
E201G & Student's final grade in Principles of Macroeconomics; $\mathrm{A}=4, \mathrm{~B}=3, \mathrm{C}=2, \mathrm{D}=1, \mathrm{E}=0$ \\
$\mathrm{E} 201 \mathrm{C}$ & Binary variable: 1 if the macroeconomics instructor curved the students' grades; 0 otherwise \\
E202G & Student's final grade in Principles of Microeconomics; $\mathrm{A}=4, \mathrm{~B}=3, \mathrm{C}=2, \mathrm{D}=1, \mathrm{E}=0$ \\
$\mathrm{E} 201 \mathrm{C}$ & Binary variable: 1 if the microeconomics instructor curved the students' grades; 0 otherwise \\
\hline \hline
\end{tabular}

As a preliminary analysis, descriptive statistics, such as means, standard deviations, and frequency distributions, was employed to describe the overall student performance and explore the difference in student performance among groups in different classifications. Table 2 reports the descriptive statistics for the sample. The mean course percentage in Introductory Corporate Finance is 67.7, or a middle to high " $\mathrm{D}$ ". This score is comparable to the mean course grades in Didia and Hasnat (1998) of 1.853 on a 4-point scale, and Chan, Shum, and Chhachhi (2005) of 69.45. The sample shows that there are more females than males. The average age of online students is 29 . Almost eighty-three percent of the students are instate students. Out of the sample, thirty-six percent of the students are majoring in accounting or finance and fifty-nine percent are transfer students. The average number of students' work hours is 32 . The mean course grade in prerequisite courses is around 3.1 on a 4.0 scale, or a low " $\mathrm{B}$ ", and the percentages of the students indicating that their instructors in prerequisite courses curved grades range from $20 \%$ to $30 \%$. 
TABLE 2

DESCRIPTIVE STATISTICS

\begin{tabular}{|l|c|c|c|c|c|}
\hline Variable & \# of Obs. & Mean & Std. Dev. & Min & Max \\
\hline F360G & 206 & 0.677 & 0.198 & 0.039 & 0.985 \\
\hline GENDER & 206 & 0.417 & 0.494 & 0 & 1 \\
\hline AGE & 206 & 29.044 & 7.951 & 18 & 58 \\
\hline FROM & 206 & 0.825 & 0.381 & 0 & 1 \\
\hline AF & 206 & 0.364 & 0.482 & 0 & 1 \\
\hline TRANSFER & 206 & 0.587 & 0.494 & 0 & 1 \\
\hline WORKHR & 206 & 32.100 & 17.830 & 0 & 76 \\
\hline M152G & 156 & 3.147 & 0.864 & 1 & 4 \\
\hline M152C & 151 & 0.285 & 0.453 & 0 & 1 \\
\hline A281G & 154 & 3.188 & 0.891 & 1 & 4 \\
\hline A281C & 152 & 0.296 & 0.458 & 0 & 1 \\
\hline A282G & 145 & 3.145 & 0.920 & 1 & 4 \\
\hline A282C & 144 & 0.243 & 0.430 & 0 & 1 \\
\hline E201G & 160 & 3.1 & 0.919 & 1 & 4 \\
\hline E201C & 159 & 0.258 & 0.439 & 0 & 1 \\
\hline E202G & 161 & 3.068 & 0.916 & 1 & 4 \\
\hline E202C & 158 & 0.203 & 0.403 & 0 & 1 \\
\hline
\end{tabular}

Table 3 shows the frequency distribution classified by age, gender, major, transfer status, and grades in prerequisite courses. The means and the standard deviations of the student performance in introductory corporate finance classes were calculated. In the Age classification, students who are younger than 20 years old have the best performance in the classes. Students who are 40 years old and older have the worst performance in the classes. The distribution shows a negative relationship between student age and student performance. In the Gender classification, female students performed better than male students, but the difference in means is not significant in the t-test $t(204)=0.261, p=0.79$. In the Major classification, students with a major in accounting or finance perform better than those with other majors, but the difference in means is not significant in the t-test $\mathrm{t}(204)=-1.055, \mathrm{p}=0.29$. In the Transfer Status classification, transferred students do not perform better than non-transferred students, and the difference in means is significant at $5 \%$ level in t-test $\mathrm{t}(204)=2.391, \mathrm{p}=0.02$. The following five panels of Table 3 show the relationship between the performance in prerequisite courses and the performance in introductory corporate finance for the sample. While the relationship between performance in college algebra, financial accounting, and macroeconomics and performance in introductory corporate finance is not clear, the frequency distribution shows a positive relationship between performance in managerial accounting and microeconomics and performance in introductory corporate finance. 
TABLE 3

FREQUENCY DISTRIBUTION

\begin{tabular}{|c|c|c|c|}
\hline & \multicolumn{3}{|c|}{ Introductory Corporate Finance } \\
\hline Age & Freq. & Mean & Std. Dev. \\
\hline Age $<20$ & 3 & 0.811 & 0.140 \\
\hline $20 \leq$ Age $<30$ & 124 & 0.687 & 0.191 \\
\hline $30 \leq$ Age $<40$ & 55 & 0.679 & 0.229 \\
\hline $40 \leq$ Age $<50$ & 19 & 0.607 & 0.160 \\
\hline Age $\geq 50$ & 5 & 0.607 & 0.122 \\
\hline \multicolumn{4}{|l|}{ Gender } \\
\hline Male & 86 & 0.673 & 0.238 \\
\hline Female & 120 & 0.680 & 0.166 \\
\hline \multicolumn{4}{|l|}{ Major } \\
\hline Accounting \& Finance & 75 & 0.697 & 0.199 \\
\hline Others & 131 & 0.666 & 0.198 \\
\hline \multicolumn{4}{|l|}{ Transfer Status } \\
\hline Transfer & 121 & 0.650 & 0.209 \\
\hline Non-transfer & 85 & 0.716 & 0.175 \\
\hline \multicolumn{4}{|l|}{ College Algebra } \\
\hline $\mathrm{A}$ & 66 & 0.705 & 0.188 \\
\hline $\mathrm{B}$ & 52 & 0.625 & 0.201 \\
\hline $\mathrm{C}$ & 33 & 0.557 & 0.210 \\
\hline $\mathrm{D}$ & 5 & 0.764 & 0.069 \\
\hline \multicolumn{4}{|l|}{ Financial Accounting } \\
\hline 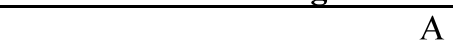 & 72 & 0.708 & 0.204 \\
\hline B & 45 & 0.599 & 0.229 \\
\hline $\mathrm{C}$ & 31 & 0.639 & 0.166 \\
\hline $\mathrm{D}$ & 6 & 0.668 & 0.133 \\
\hline \multicolumn{4}{|l|}{ Managerial Accounting } \\
\hline $\bar{A}$ & 65 & 0.705 & 0.204 \\
\hline B & 44 & 0.665 & 0.195 \\
\hline $\mathrm{C}$ & 28 & 0.599 & 0.172 \\
\hline $\mathrm{D}$ & 8 & 0.598 & 0.258 \\
\hline \multicolumn{4}{|l|}{ Macroeconomics } \\
\hline $\bar{A}$ & 65 & 0.764 & 0.151 \\
\hline B & 57 & 0.647 & 0.194 \\
\hline $\mathrm{C}$ & 27 & 0.631 & 0.123 \\
\hline $\mathrm{D}$ & 11 & 0.659 & 0.126 \\
\hline \multicolumn{4}{|l|}{ Microeconomics } \\
\hline (1) & 65 & 0.730 & 0.173 \\
\hline B & 50 & 0.659 & 0.213 \\
\hline $\mathrm{C}$ & 38 & 0.609 & 0.196 \\
\hline $\mathrm{D}$ & 8 & 0.466 & 0.275 \\
\hline
\end{tabular}

\section{EMPIRICAL RESULTS}

Inferential statistics, such as t-test and regression analysis, was employed to analyze the data to examine whether grading on a curve in prerequisite courses can lead to a difference in student performance in online introductory corporate finance. Table 4 shows the t-test results for difference in means of course grade in online Introductory Corporate Finance between no-curved prerequisite and curved prerequisite courses. The results show that students who did not receive curved grades in 
prerequisite courses (except for financial accounting) generally perform better than those who received curved grades in prerequisite courses, but the difference is not significant.

TABLE 4

TEST OF DIFFERENCES IN MEAN OF COURSE GRADE

\begin{tabular}{|l|c|c|c|c|}
\hline & \multicolumn{3}{|c|}{ Course Grade in Introductory Corporate } \\
\hline & Mean & t-stat & df & p-value \\
\hline No curve grading in College Algebra & $\begin{array}{l}0.655 \\
0.635\end{array}$ & 0.525 & \multirow{2}{*}{149} & \multirow{2}{*}{0.600} \\
Curve grading in College Algebra & $\begin{array}{l}0.656 \\
0.669\end{array}$ & -0.356 & \multirow{2}{*}{150} & \multirow{2}{*}{0.723} \\
\hline $\begin{array}{l}\text { No curve grading in Principles of Financial Accounting } \\
\text { Curve grading in Principles of Financial Accounting }\end{array}$ & $\begin{array}{l}0.668 \\
0.650\end{array}$ & \multirow{2}{*}{0.459} & \multirow{2}{*}{142} & \multirow{2}{*}{0.647} \\
\hline No curve grading in Principles of Managerial Accounting \\
Curve grading in Principle of Managerial Accounting
\end{tabular}

Existing financial education studies focusing on the determinants of student performance have adopted a model based on the standard production function approach, where output is the grade received and inputs are factors incorporating student characteristics such as gender, maturity, background, specialization, and effort. Since the dependent variable (F360G) in this study is continuous in nature, the ordinary-least-squares regression analysis is employed. The independent variables were described in Table 1.

Table 5 provides the regression coefficients and their p-values (in parentheses) from the ordinary least squares estimation with a correction for heteroscedasticity. Equation (1) focuses on the relationship between performance in college algebra and performance in introductory corporate finance. Equation (2) focuses on the relationship between performance in financial accounting and performance in introductory corporate finance. Equation (3) focuses on the relationship between performance in managerial accounting and performance in introductory corporate finance. Equation (4) focuses on the relationship between performance in macroeconomics and performance in introductory corporate finance. Finally, Equation (5) focuses on the relationship between performance in microeconomics and performance in introductory corporate finance.

The coefficients for the age variable (AGE) are negative and significant at the 5\% level in Equations (4) and (5) and at 10\% level in Equation (1), indicating that older students tend to perform worse in the online introductory corporate finance course than younger students. This result is contrary to those reported by Didia and Hasnat (1998), Shum and Chan (2000), and Chan et al. (2005) in traditional or interactive television course delivery settings. Student motivation proxied by student major (AF) has positive coefficients with significance at the 5\% level in Equations (1) and (2) and at the level 10\% in Equation (4), suggesting that accounting and finance students tend to perform better than students with other majors. This finding is consistent with those reported by Shum and Chan (2000), Terry (2002), and Chan et al. (2005) in traditional or interactive television course delivery settings. Educational experience proxied by students' transfer status (TRANSFER) has negative coefficients with significance at the 5\% level in Equations (2) and (5) and at the level 10\% in Equation (3), implying that students who transfer from other colleges (2-year and 4-year) tend to perform worse than students who start higher education at the university in the study. This finding is in line with Borde et al. (1998) who also find that students who 
transfer from community colleges tend to perform worse in a traditional course delivery setting. The coefficients of WORKHR are negative and significant at the 5\% level in all equations except Equation (5), suggesting that students having long work hours tend to perform worse than students without long work hours. This is not surprising as more hours of work may reduce study time for the finance course materials. This result concurs with the finding of Borde et al. (1998) who report that students having long employment hours perform worse in the introductory finance course delivered in a traditional setting.

Focusing on individual estimates of prerequisite courses, the coefficients of all prerequisites courses (M152G, A281G, A282G, E201G, and E202G) are positive and significant at 5\% level, suggesting that students who have higher grades in prerequisite courses perform better in online introductory corporate finance classes than those who have lower grades in prerequisite courses. This finding agrees with Didia and Hasnat (1998), Borde et al. (1998) and Terry (2002), and Raehsler et al. (2012) who report that high performance in accounting, economics, and mathematics prerequisite courses is associated with high performance in the introductory finance course delivered in a traditional setting. The interactions terms $(\mathrm{M} 152 \mathrm{C} \times \mathrm{M} 152 \mathrm{G}, \mathrm{A} 281 \mathrm{C} \times \mathrm{A} 281 \mathrm{G}, \mathrm{A} 282 \mathrm{C} \times \mathrm{A} 282 \mathrm{G}, \mathrm{E} 201 \mathrm{C} \times \mathrm{E} 201 \mathrm{G}$, and E202C $\times \mathrm{E} 202 \mathrm{G})$ are employed to measure whether there is any difference in performance between students who have and who do not have their grades curved in prerequisite courses. The coefficients of all interaction terms have inconsistent signs and are not significant, implying that there is no difference in performance between students who had and who did not have their grades curved in prerequisite courses. 
TABLE 5

ORDINARY LEAST SQUARES REGRESSION RESULTS

\begin{tabular}{|c|c|c|c|c|c|}
\hline Variable & Equation (1) & Equation (2) & Equation (3) & Equation (4) & Equation (5) \\
\hline Intercept & $\begin{array}{c}0.698 \\
(0.000)\end{array}$ & $\begin{array}{c}0.748 \\
(0.000)\end{array}$ & $\begin{array}{c}0.721 \\
(0.000)\end{array}$ & $\begin{array}{c}0.698 \\
(0.000)\end{array}$ & $\begin{array}{c}0.676 \\
(0.000)\end{array}$ \\
\hline GENDER & $\begin{array}{c}-0.047 \\
(0.238) \\
\end{array}$ & $\begin{array}{c}-0.042 \\
(0.268) \\
\end{array}$ & $\begin{array}{l}-0.025 \\
(0.505)\end{array}$ & $\begin{array}{l}-0.020 \\
(0.529)\end{array}$ & $\begin{array}{c}-0.044 \\
(0.235)\end{array}$ \\
\hline AGE & $\begin{array}{c}-0.003 \\
(0.092)\end{array}$ & $\begin{array}{c}-0.002 \\
(0.206)\end{array}$ & $\begin{array}{l}-0.003 \\
(0.169) \\
\end{array}$ & $\begin{array}{l}-0.003 \\
(0.023) \\
\end{array}$ & $\begin{array}{c}-0.004 \\
(0.023) \\
\end{array}$ \\
\hline FROM & $\begin{array}{c}-0.022 \\
(0.646) \\
\end{array}$ & $\begin{array}{c}-0.054 \\
(0.225) \\
\end{array}$ & $\begin{array}{c}-0.034 \\
(0.474)\end{array}$ & $\begin{array}{c}-0.033 \\
(0.419) \\
\end{array}$ & $\begin{array}{c}-0.044 \\
(0.319) \\
\end{array}$ \\
\hline $\mathrm{AF}$ & $\begin{array}{c}0.075 \\
(0.040) \\
\end{array}$ & $\begin{array}{c}0.084 \\
(0.037) \\
\end{array}$ & $\begin{array}{c}0.063 \\
(0.144)\end{array}$ & $\begin{array}{c}0.053 \\
(0.077) \\
\end{array}$ & $\begin{array}{c}0.054 \\
(0.113) \\
\end{array}$ \\
\hline TRANSFER & $\begin{array}{c}-0.046 \\
(0.238) \\
\end{array}$ & $\begin{array}{c}-0.079 \\
(0.048) \\
\end{array}$ & $\begin{array}{c}-0.072 \\
(0.076)\end{array}$ & $\begin{array}{l}-0.047 \\
(0.181)\end{array}$ & $\begin{array}{c}-0.103 \\
(0.004)\end{array}$ \\
\hline WORKHR & $\begin{array}{c}-0.002 \\
(0.002)\end{array}$ & $\begin{array}{c}-0.002 \\
(0.036)\end{array}$ & $\begin{array}{c}-0.002 \\
(0.055)\end{array}$ & $\begin{array}{l}-0.001 \\
(0.039)\end{array}$ & $\begin{array}{c}-0.001 \\
(0.153) \\
\end{array}$ \\
\hline M152G & $\begin{array}{c}0.046 \\
(0.020) \\
\end{array}$ & & & & \\
\hline $\mathrm{M} 152 \mathrm{C} \times \mathrm{M} 152 \mathrm{G}$ & $\begin{array}{c}-0.008 \\
(0.421) \\
\end{array}$ & & & & \\
\hline $\mathrm{A} 281 \mathrm{G}$ & & $\begin{array}{c}0.037 \\
(0.030) \\
\end{array}$ & & & \\
\hline $\mathrm{A} 281 \mathrm{C} \times \mathrm{A} 281 \mathrm{G}$ & & $\begin{array}{c}0.002 \\
(0.863) \\
\end{array}$ & & & \\
\hline $\mathrm{A} 282 \mathrm{G}$ & & & $\begin{array}{c}0.043 \\
(0.055) \\
\end{array}$ & & \\
\hline $\mathrm{A} 282 \mathrm{C} \times \mathrm{A} 282 \mathrm{G}$ & & & $\begin{array}{l}-0.005 \\
(0.653)\end{array}$ & & \\
\hline E201G & & & & $\begin{array}{c}0.054 \\
(0.000) \\
\end{array}$ & \\
\hline $\mathrm{E} 201 \mathrm{C} \times \mathrm{E} 201 \mathrm{G}$ & & & & $\begin{array}{c}-0.001 \\
(0.886) \\
\end{array}$ & \\
\hline E202G & & & & & $\begin{array}{c}0.080 \\
(0.000)\end{array}$ \\
\hline $\mathrm{E} 202 \mathrm{C} \times \mathrm{E} 202 \mathrm{G}$ & & & & & $\begin{array}{c}-0.000 \\
(0.982) \\
\end{array}$ \\
\hline \# of observations & 150 & 152 & 143 & 158 & 158 \\
\hline R-squared & 0.155 & 0.141 & 0.133 & 0.166 & 0.217 \\
\hline
\end{tabular}

\section{CONCLUSION}

This research study investigates whether students receiving curved grades in prerequisite courses have comparable performance in online introductory corporate finance classes. Research studies have shown a positive relationship between student performance in accounting, economics and mathematics prerequisite courses and student performance in introductory corporate finance. This relationship may be questionable in the existence of grading on a curve or perhaps grade inflation. Based on a sample of 206 students, tests of mean differences across whether or not grades are curved in five prerequisite courses 
indicate that students who did not receive curved grades in prerequisite courses (except for financial accounting) generally perform better than those who received curved grades in prerequisite courses, but the difference is not significant. The result is confirmed by an ordinary least squares regression. Regression results also indicate that student's age, major, educational experience, number of student work hours and performance in prerequisite courses appear to significantly affect student performance. Older students perform worse than younger students. Accounting and finance students perform better than students with other majors. Students who transfer from other universities do not perform as well as students who begin higher education at the university in the study. Students having long work hours perform worse than students without long work hours. Students who receive high grades in prerequisite courses perform better in online introductory corporate finance classes than students who receive low grades in prerequisite courses.

Because the sample used in this study was obtained from students in a business core course under one instructor at one university, this research represents only a preliminary attempt at this issue. Collecting student data from different institutions to increase the sample size may lead to more robust findings. The research methodology in this study can be used by other disciplines to examine the difference in student performance between students who have their grades curved and students who do not have their grades curved in prerequisite courses.

\section{REFERENCES}

Arbaugh, J.B., Godfrey, M.R., Johnson, M., Pollack, B.L., Niendorf, B. \& Wresch, W. (2009) Research in online and blended learning in the business disciplines: Key findings and possible future directions. Internet and Higher Education, 12, 71-87.

Al-Saleh, M.F., Ali, D. \& Dahshal, L. (2010). Towards a reference curve for the grades of each course. International Journal of Mathematical Education in Science and Technology, 41, (4), 547-555.

Aviles, C.B. (2001). Grading with norm-referenced or criterion-referenced measurements: To curve or not to curve, that is the question. Social Work Education, 20, (5), 603-608.

Barth, M.M., Liu, J. \& Wells, W.H. (2009). A comparative analysis of grading practices by discipline within a college of business. Academy of Educational Leadership Journal, 13, (4), 93-107.

Bailey, G.L. \& Steed, R.C. (2012). The impact of grading on a curve: Assessing the results of Kulick and Wright's simulation analysis. International Journal for the Scholarship of Teaching and Learning, 6, (1), Article 11. Retrieved from https://doi.org/10.20429/ijsotl.2012.060111

Becker, W.E. (1997). Teaching economics to undergraduates. Journal of Economic Literature, 35, (3), 1347-1373.

Borde, S.F., Byrd, A.K. \& Modani, N.K. (1998). Determinants of student performance in introductory corporate finance courses. Journal of Financial Education, 24, 23-30.

Chan, K.C., Shum C. \& Chhachhi, I. (2005). The performance of transfer versus 'native' students in principles of finance. Journal of Financial Education, 31, 50-63.

Chang, C., Lawrence, E. \& Prakash, A. (2012). Face-to-face and online finance courses: An assessment. International Journal of Finance, 24, 7209-7218.

Cluskey Jr., G.R. \& Griffin, N. (1997). Accounting grade inflation. Journal of Education for Business, 72, (5), 273-277.

Didia, D. \& Hasnat, B. (1998). The determinants of performance in the university introductory finance course. Financial Practice and Education, 8, (1), 102-107.

Farinella, J. (2007). Professor and student performance in online versus traditional introductory finance courses. Journal of Economics and Finance Education, 6, (1), 40-47.

Hanson, D., Quin, F. \& Wells, W. (2002). Grade inflation at the college level: An empirical examination of GPA. Journal of Business, Industry and Economics, 2, 37-43.

$\mathrm{Hu}, \mathrm{S}$. (2005). Beyond grade inflation: Grading problems in higher education. ASHE Higher Education Report, 30, (6), 1-99. 
Kezim, B., Pariseau, S.E. \& Quinn, F. (2005). Is grade inflation related to faculty status? Journal of Education for Business, 80, (6), 358-363.

Kidwell, L.A. \& Kidwell, R.E. (2008). Do the numbers add up to different views? Perceptions of ethical faculty behavior among faculty in quantitative versus qualitative disciplines. Journal of Business Ethics, 78, (1), 141-151.

Kulick, G. \& Wright, R. (2008). The impact of grading on the curve: A simulation analysis. International Journal for the Scholarship of Teaching and Learning, 2, (2), Article 5. Retrieved from https://doi.org/10.20429/ijsotl.2008.020205

Raehsler, R.D., Hung, K., Yang, C.W. \& Stuhldreher, T.J. (2012). Are mathematics, economics, and accounting courses important determinants in financial management: A rank order approach. Journal of Economics and Finance Education, 11, (1), 48-59.

Rapaport, W. (2011). A triage theory of grading: the good, the bad, and the middling. Teaching Philosophy, 34, (4), 347-372.

Shum, C. \& Chan, K.C. (2000). The effectiveness of interactive television distance learning in principles of finance. Financial Practice and Education, 10, (1), 175-183.

Sonner, B.S. (2000). A is for "adjunct": Examining grade inflation in higher education. Journal of Education for Business, 76, (1), 5-8.

Stroebe, W. (2016). Why good teaching evaluations may reward bad teaching: On grade inflation and other unintended consequences of student evaluations. Perspectives on Psychological Science, $11,(6), 800-816$.

Terry, A. (2002). Student performance in the introductory corporate finance course. Journal of Financial Education, 28, 28-41.

Van Ness, B.F., Van Ness, R.A. \& Adkins, R.L. (2000). Student performance in principles of finance: difference between traditional and internet settings. Financial Practice and Education, 10, (2), 160-166.

Walstad, W.B. \& Miller, L.A. (2016). What's in a grade? Grading policies and practices in principles of economics. The Journal of Economic Education, 47, (4), 338-350.

Wedell, D., Parducci, A. \& Roman, D. (1989). Student perceptions of fair grading: A range-frequency analysis. The American Journal of Psychology, 102, 233-248. 